Western University

Scholarship@Western

Obstetrics \& Gynaecology Publications

Obstetrics \& Gynaecology Department

5-1-2008

\title{
Bovine oocytes and early embryos express Staufen and ELAVL RNA-binding proteins.
}

M D Calder

P Madan

AJ Watson

Follow this and additional works at: https://ir.lib.uwo.ca/obsgynpub

Part of the Obstetrics and Gynecology Commons

Citation of this paper:

Calder, M D; Madan, P; and Watson, A J, "Bovine oocytes and early embryos express Staufen and ELAVL RNA-binding proteins." (2008). Obstetrics \& Gynaecology Publications. 73.

https://ir.lib.uwo.ca/obsgynpub/73 
For Submission to Zygote:

\section{Bovine Oocytes and Early Embryos Express Staufen and ELAVL RNA Binding Proteins}

Michele D. Calder ${ }^{1}$, Pavneesh Madan ${ }^{2}$, and Andrew J. Watson, Ph.D. ${ }^{1}$

${ }^{1}$ Departments of Physiology and Pharmacology, and Obstetrics and Gynaecology, The University of Western Ontario; Children's Health Research Institute, London, Ontario, Canada; ${ }^{2}$ Department of Biomedical Sciences, University of Guelph, Guelph, Ontario, Canada

Corresponding Author: Dr. A.J. Watson. Departments of Physiology and Pharmacology, and Obstetrics and Gynaecology, The University of Western Ontario; Children's Health Research Institute-LHRI, $5^{\text {th }}$ Floor Victoria Research Laboratories, 800 Commissioners Road, London, Ontario, Canada N6A 4G5; awatson@uwo.ca, tel :(519) 685-8500x55068; fax (519) 685-8186.

Running Title: RNA binding proteins in cow embryos 


\begin{abstract}
:
RNA binding proteins (RBP) influence RNA editing, localization, stability and translation and may contribute to oocyte developmental competence by regulating the stability and turnover of oogenetic mRNAs. The expression of Staufen 1 and 2 and ELAVL1, ELAVL2 RNA binding proteins during cow early development was characterized. Cumulus-oocyte complexes were collected from slaughterhouse ovaries, matured, inseminated and subjected to embryo culture in vitro. Oocyte or preimplantation embryo pools were processed for RT-PCR and whole-mount immunofluorescence analysis of mRNA expression and protein distribution. STAU1 and STAU2, and ELAVL1 mRNAs and proteins were detected throughout cow preimplantation development from the germinal vesicle (GV) oocyte to the blastocyst stage. ELAVL2 mRNAs were detectable from the GV to the morula stage whereas ELAVL2 protein was in all stages examined and localized to both cytoplasm and nuclei. The findings provide a foundation for investigating the role of RBPs during mammalian oocyte maturation and early embryogenesis.
\end{abstract}

Key words: oogenesis, blastocyst, in vitro fertilization, gene expression, transcripts 


\section{INTRODUCTION:}

Oocyte cytoplasmic maturation involves the accumulation of mRNAs, proteins, substrates and nutrients that are required to achieve the oocyte developmental competence that fosters embryonic development (Calder et al., 2003; Calder et al., 2001). RNA binding proteins (RBP) influence RNA editing, localization, stability and translation (Saunders and Barber, 2003). Therefore RBPs may contribute to oocyte competence by regulating the stability and turnover of oogenetic mRNAs. In addition, variations in oocyte competence may reflect differences in RBP levels and thus turnover of their target mRNAs during early development.

As a prelude to investigating these possibilities it is imperative that the expression of RBPs during mammalian oocyte maturation and early embryogenesis be first determined. Staufen is a Drosophila RBP that assists in establishing the anterior-posterior embryonic axis by regulating target mRNA localization in the Drosophila oocyte (St Johnston et al., 1991). There are two mammalian staufen genes, STAU1 (Marion et al., 1999) and STAU2 (Duchaine et al., 2000). ELAVL1 (HuR, HuA, elrA) is a widely expressed RBP (Fan and Steitz, 1998), which is present in the Xenopus embryo (Good, 1995) and can shuttle between the nucleus and cytoplasm (Atasoy et al., 1998). It binds to A-U rich sequences (AREs) to regulate mRNA half-life (Atasoy et al., 1998; Fan and Steitz, 1998). ELAVL2 (HuB, elrB, Hel-N1/2) is also an ARE binding RBP (Jain et al., 1997), which is predominantly neuronal but is also expressed in the ovary, testis, oocyte and Xenopus embryo (Good, 1995). ELAVL2 affects mRNA degradation, and may increase protein translation (Jain et al., 1997). The present study was conducted to characterize the expression of Staufen and ELAVL mRNAs and proteins during oocyte maturation and preimplantation development in the cow. 


\section{MATERIALS AND METHODS:}

\section{Production of Bovine Embryos In Vitro}

Cumulus-oocyte complexes were isolated, placed into oocyte maturation and were fertilized in vitro and cultured up to the blastocyst stage as outlined in (Madan et al., 2005). Bovine ovaries were transported from a slaughterhouse in sterile saline at $32-37^{\circ} \mathrm{C}$ for oocyte collection using standard protocols. Cumulus-oocyte complexes (COCs) from 3-6 mm follicles were aspirated into the follicular aspiration medium consisting of Dulbecos's phosphate buffered saline (Gibco BRL; Invitrogen, Burlington, ON), 0.3\% bovine serum albumin (Sigma-Aldrich Canada Ltd, Oakville, ON) and $50 \mu \mathrm{g} / \mathrm{ml}$ Gentamycin (Sigma-Aldrich Canada Ltd.) using an 18G needle attached to vacuum suction apparatus. COCs that contained an oocyte with an evenly granulated cytoplasm and surrounded by more than three layers of cumulus cells were selected for maturation in vitro. For maturation in vitro COCs were cultured in oocyte maturation medium composed of modified synthetic oviductal fluid (SOF) medium with $0.8 \%$ BSA, modified Eagle medium (MEM) non essential amino acids (Gibco), MEM essential amino acids (Gibco), $1 \mathrm{mM}$ glutamine, $0.5 \% \mu \mathrm{g} / \mathrm{ml} \mathrm{FSH}$ and $1 \mu \mathrm{g} / / \mathrm{ml} 17 \beta$-estradiol. 50 COCs were placed in each well of a 4-well culture plate and incubated in a humidified atmosphere for $24 \mathrm{~h}$ at $38.5^{\circ} \mathrm{C}$ and $5 \% \mathrm{CO}_{2}$ in air atmosphere.

For fertilization in vitro, 50 mature COCs were added to $330 \mu \mathrm{l}$ drops containing modified Tyrode lactate medium (TLH) supplemented with 0.6\% BSA fatty acid free (Sigma-Aldrich), $0.2 \mathrm{mM}$ pyruvic acid, $10 \mu \mathrm{g} / \mathrm{ml}$ heparin and $50 \mu \mathrm{g} / \mathrm{ml}$ gentamycin under mineral oil. Frozen semen was thawed and processed through a standard "swim-up" method (Madan et al., 2005). Sperm concentration was adjusted to and added to each insemination culture drop at $1 \times 10^{6}$ spermatozoa/ml. COCs and spermatozoa were co-incubated in a humidified $5 \% \mathrm{CO}_{2}$ in air atmosphere at $38.5^{\circ} \mathrm{C}$ and for $15-18 \mathrm{~h}$. 
Following fertilization, zygotes were denuded of investing cumulus cells by vortexing, washing three times in culture media consisting of SOF1 plus $0.8 \%$ BSA, MEM non essential amino acids, $1 \mathrm{mM}$ glutamine and $1.5 \mathrm{mM}$ glucose and $10 \mu \mathrm{M}$ EDTA. Subsequently, 20-30 zygotes were placed into $50 \mu \mathrm{l}$ culture drops under mineral oil and cultured at $38.5^{\circ} \mathrm{C}, 5 \% \mathrm{CO}_{2}$, and humidified air with reduced oxygen atmosphere (7\%). Following 3 days of culture, SOF1 medium was replaced with SOF2 medium, which contained 0.8\%, BSA, MEM non essential amino acids, MEM essential amino acids, $1 \mathrm{mM}$ glutamine and $1.5 \mathrm{mM}$ glucose. Pools of 20 embryos were harvested at timed stages of development [2-, 4-, 8cells, morulae, and blastocysts] for RNA extraction or application of immunofluorescence localization methods.

\section{Primer Design}

Primer sets were designed to recognize and amplify conserved nucleotide sequences encoding human and murine Staufen or ELAVL cDNAs. cDNA sequences and/or homologue(s) were identified using BLAST (Basic Local Alignment Search Tool) computer program (NCBI, Bethesda, MD). Primers were designed using the 'Primer3' computer program (Whitehead Institute, Cambridge, MA) and the corresponding oligonucleotides (Table 1), were synthesized (Invitrogen, Burlington, ON).

\section{RNA extraction, reverse transcription and PCR}

Total RNA was extracted from bovine embryos (pools of 20 embryos/stage at 1-, 2-, 4-, 8-cell, morula and blastocyst stages) as described (Madan et al., 2005). The total RNA extracts were digested with deoxyribonuclease (DNAse)-1 to eliminate possible contamination from genomic DNA. The RT reactions were conducted using oligo-dT primers (Gibco BRL) as previously described (Barcroft et al., 1998; Calder et al., 2005; Calder et al., 2003; Calder et al., 2001; Natale et al., 2004; Offenberg et al., 
2000). Samples were incubated for $90 \mathrm{~min}$ at $42^{\circ} \mathrm{C}$ in a $20 \mu \mathrm{l}$ volume of 50mM Tris- $\mathrm{HCl}(\mathrm{pH} 8.3$ ), 75 mM KCl, 3 mM MgCl2, 10 mM DTT, 0.5 mM dNTPs, and 200 units of Superscript II (Gibco BRL) followed by heating the samples to $95^{\circ} \mathrm{C}$ for 5 min reaction termination.

PCR was conducted as described (Calder et al., 2005; Calder et al., 2003; Calder et al., 2001). Briefly, two embryo equivalents for each stage of development under investigation were used per PCR reaction, which was repeated a minimum of three times from pools of three different developmental series of embryos. PCR products were resolved on $2.0 \%$ agarose gels containing $0.5 \mu \mathrm{g} / \mathrm{ml}$ ethidium bromide (Invitrogen, Burlington, ON). To confirm the specificity of each PCR product, representative amplicons were extracted from the gels and purified using a QIAquick Gel Extraction Kit (Qiagen, Mississauga, ON) and submitted for nucleotide sequencing (DNA Sequencing Facility, Robarts Research Institute, London, ON, Canada). The nucleotide sequences were compared to sequences available in GenBank to confirm the specificity of each PCR product.

\section{Whole-mount indirect immunofluorescence}

To localize Staufen and ELAVL proteins in bovine oocytes and preimplantation embryos we employed whole-mount immunofluorescence methods as outlined in (Calder et al., 2005; Calder et al., 2003; Calder et al., 2001; Madan et al., 2005). Embryos (oocytes, 2-, 4- 8-cell, morula and blastocyst stages) were washed in $1 \mathrm{X}$ phosphate buffer saline (PBS) and then fixed in 2\% paraformaldehyde (PFA) in PBS for $20 \mathrm{~min}$ at room temperature. These fixed embryos were washed in $1 \mathrm{X}$ PBS and either processed immediately for immuno-labeling or stored at $4^{\circ} \mathrm{C}$ in $\mathrm{PBS}+0.09 \%$ sodium azide for a maximum of 3 weeks. Fixed embryos were permeabilized and blocked in 1X PBS + 5\% goat Serum + 0.01\% Triton X-100 for 1 hour at room temperature. Embryos were washed in 1X PBS and incubated with primary antibody diluted 1:100 in $1 \mathrm{X}$ PBS $+1 \%$ goat Serum $+0.005 \%$ Triton $\mathrm{X}-100$ for one hour at 
room temperature followed by additional washes totaling 1 hour at $37^{\circ} \mathrm{C}$. Primary antibodies were detected by exposure for one hour to FITC-conjugated secondary antibodies (Jackson Immuno Labs, MA, USA) diluted 1:200. Embryos were then treated with rhodamine-conjugated phalloidin $(5 \mu \mathrm{g} / \mathrm{ml}$; 1:20) and DAPI (1mg/ml; 1:2000) for 30 minutes at $37^{\circ} \mathrm{C}$ followed by 2 washes for 2 hours each at $37^{\circ} \mathrm{C}$. Embryos were mounted in Fluoro-Guard Antifade Mounting Reagent (BioRad, Mississauga, ON, Canada). Fluorescence patterns were examined using a Zeiss LSM 410 (laser scanning microscope) with an inverted Axiovert 100 microscope under 20-40X magnification. The images were then captured and stored as TIFF files by the Zeiss LSM software package. Rabbit polyclonal anti-human STAU1, ELAVL1 and ELAVL2 antibodies were obtained from (Chemicon, Temecula, CA).

\section{RESULTS AND DISCUSSION:}

STAU1 mRNA was detected from the germinal vesicle (GV) oocyte to the blastocyst stage (Fig. 1A). The primers used to amplify STAU1 revealed two mRNA isoforms expressed in oocytes and embryos, which differ due to a splicing event resulting in an insertion of 18bp (6aa) in RNA binding domain 3, similar to isoforms reported in mouse (Duchaine et al., 2000). STAU1 protein was detected in the cytoplasm of bovine oocytes and embryos at all stages examined (Fig.1C-K). Staufen was observed in the GV, pronuclei or nuclei up to the morula stage but this localization was rarely stronger than cytoplasmic fluorescence (Fig. 1 C-K). STAU2 mRNA was also detected in all cow preimplantation stages (Figure 1B). ELAVL1 mRNA was detected continuously from the GV oocyte to the blastocyst stage (Fig. 2A). ELAVL1 protein was cytoplasmic at all stages examined, but was also present in the GV and most nuclei at all stages, but was less evident at the blastocyst stage (Fig. 2 C-K). ELAVL2 mRNAs were detected from the GV oocyte to the 8-cell stage in all replicates (Fig. 2B). ELAVL2 mRNA was detected only in some replicates at the morula stage and not at all at the blastocyst stage 
(Fig. 2B). Two ELAVL2 mRNAs were detected. The larger band corresponds to a 539bp product common to human and mouse sequences in Genbank (mouse, NM_207685). In the mouse, there is an ELAVL2 mRNA splice variant lacking 36nt, this isoform would amplify as 503bp (NM_207686). Another isoform lacks the bases AGG (R) before this splice junction, the 36 bp and has the addition of AGT (S) at the end of the splice junction, making it also 503bp (AY035379). Yet another splice variant reported contains the 5' R, misses the 36nt, and contains the 3' S, making it 506bp (AY035378). However, a human variant contains only 500bp and the 5' R, the 36nt and the 3' S are missing (BC030692). ELAVL2 immunofluorescence was cytoplasmic at all stages examined, but was also detectable in the GV, pronuclei and most nuclei, and was brighter in the nucleus than cytoplasm at particularly the 4- and 8-cell stages (Fig. 2 L-T). At the blastocyst stage, ELAVL2 also appeared at the borders of trophectoderm cells (Fig. 2S).

As the vast majority of mammalian in vitro matured oocytes are meiotically competent, deficiencies in cytoplasmic maturation are proposed as a primary reason for their low developmental rates. Transcription and storage of maternal mRNAs occurs during follicular growth and slows as the oocyte reaches mature size (Fair et al., 1995). The embryo is dependent on stored maternal mRNAs until at least the maternal-zygotic transition (MZT), when transcription of embryonic genes begins in earnest with a major burst of embryonic transcription initiating at the 8-cell stage in the cow (Telford et al., 1990). Many maternal mRNAs become deadenylated during oocyte maturation and early cleavage (Brevini-Gandolfi et al., 1999). Over 200 RBP candidate genes have been identified in Drosophila (Lasko, 2000). Regulated mRNA stability occurs in mammalian cells in response to nutrient levels, hormones and environmental stresses such as hypoxia and heat stress (reviewed by (Guhaniyogi and Brewer, 2001). It has been suggested that variations in transcriptional activity largely govern changes in embryonic mRNA abundance associated with exposure to sub-optimal environments (Niemann and 
Wrenzycki, 2000). However, oocyte and embryo competence could also be affected by environmental effects acting through RBPs to alter transcript stability or translation.

During oogenesis, oocytes acquire a depository of maternally-encoded transcripts that must be stored and remain dormant until their translation is required following oocyte activation and insemination. This delay between their production and translation is important as the oocyte becomes transcriptionally silent during the final stages of folliculogenesis and transcription is not renewed until post-insemination and early embryogenesis (Schultz, 2005). Yet few studies have investigated mRNA stability during preimplantation development. Instead, the majority of studies have focused upon understanding transcriptional regulation (Knijn et al., 2002; Knijn et al., 2005; Niemann and Wrenzycki, 2000; Rinaudo and Schultz, 2004; Wrenzycki et al., 1999; Wrenzycki et al., 2005). Our study provides the first indications that gene products encoding Staufen and ELAVl RBPs are expressed during bovine preimplantation development.

Preimplantation mammalian embryos attempt to respond positively to the pressures that suboptimal culture environments place upon them (Ho et al., 1994; Ho et al., 1995; Niemann and Wrenzycki, 2000; Watson et al., 2000). The embryo, (at least partially), compensates for missing components or offsets the presence of deleterious components, by regulating its developmental program (Niemann and Wrenzycki, 2000). This capacity however must operate within a defined range of tolerances, (Bavister, 2000; Bolton, 1992; Gardner et al., 2002; Leese, 2002; Schultz and Williams, 2002) and current media, are still sub-optimal for all species. We are aware that current media are still sub-optimal since cultured embryos from all species display a reduced pregnancy rate following embryo transfer, and are also prone to metabolic and growth disorders that may find their origin in a culture induced "metabolic re-programming" during the preimplantation development period as compared to their in vivo derived counterparts (Adamiak et al., 2005; Barker, 2003; Boerjan et al., 2000; McEvoy et 
al., 2001; McEvoy et al., 2000; Sinclair et al., 1999; Sinclair et al., 2003; van Wagtendonk-de Leeuw et al., 2000).

Due to these concerns great effort has been focused on understanding how early embryos adjust their developmental program to compensate for exposure to sub-optimal culture environments. Approaches in this research area have included studies directly comparing the levels of "marker" gene expression, also variations in embryo metabolism between in vitro and in vivo derived preimplantation embryos and most recently epigenetic re-programming as signified by variation in DNA methylation patterns (Brevini-Gandolfi et al., 1999; De Sousa et al., 1998; Ecker et al., 2004; Knijn et al., 2005; Leese, 2002; Mann et al., 2004; Watson et al., 2000; Wrenzycki et al., 1999; Wrenzycki et al., 2005). The prevailing interpretation of the majority of these studies is that gene transcription is influenced by exposure to varying culture environments. Only a very few studies have begun to examine the influences of varying culture environments on mRNA deadenylation, and mRNA stability (Brevini-Gandolfi et al., 1999; Gandolfi and Gandolfi, 2001; Temeles and Schultz, 1997). In addition, there is a need to understand the role of RBPs in regulating preimplantation mRNA stability as these proteins represent reasonable targets for culture induced influences on embryonic mRNAs (Yang et al., 2005; Yang et al., 2006; Yang et al., 2005; Yu et al., 2003). This study therefore provides a foundation for investigating the roles of RBPs during early development and will allow for investigations regarding their putative roles in regulating preimplantation development and more importantly, eventually, their collective roles in regulating mRNA transcripts during early embryogenesis.

\section{ACKNOWLEDGEMENTS:}

The authors would like to thank Barry Fong and Jenny Hickson for help with transporting ovaries and ovarian aspiration. We would like to thank Dr. Allan King's and Dr Dean Betts’ laboratories 
at the University of Guelph for assisting with ovary collections. These studies were supported by operating funds from the Natural Sciences and Engineering Research Council of Canada (NSERC) Discovery Grant \# 138317-06.

\section{REFERENCES:}

Adamiak, S. J., Mackie, K., Watt, R. G., Webb, R. and Sinclair, K. D. (2005). Impact of nutrition on oocyte quality: cumulative effects of body composition and diet leading to hyperinsulinemia in cattle. Biol Reprod 73, 918-26.

Atasoy, U., Watson, J., Patel, D. and Keene, J. D. (1998). ELAV protein HuA (HuR) can redistribute between nucleus and cytoplasm and is upregulated during serum stimulation and T cell activation. $J$ Cell Sci 111 (Pt 21), 3145-56.

Barcroft, L. C., Hay-Schmidt, A., Caveney, A., Gilfoyle, E., Overstrom, E. W., Hyttel, P. and Watson, A. J. (1998). Trophectoderm differentiation in the bovine embryo: characterization of a polarized epithelium. J Reprod Fertil 114, 327-39.

Barker, D. J. (2003). The developmental origins of adult disease. Eur J Epidemiol 18, 733-6.

Bavister, B. D. (2000). Interactions between embryos and the culture milieu. Theriogenology 53, 61926.

Boerjan, M. L., den Daas, J. H. and Dieleman, S. J. (2000). Embryonic origins of health: long-term effects of IVF in human and livestock. Theriogenology 53, 537-47.

Bolton, V. N. (1992). Controversies and opinions in embryo culture: two- to four-cell transfer vs blastocyst. J Assist Reprod Genet 9, 506-8.

Brevini-Gandolfi, T. A., Favetta, L. A., Mauri, L., Luciano, A. M., Cillo, F. and Gandolfi, F. (1999). Changes in poly(A) tail length of maternal transcripts during in vitro maturation of bovine oocytes and their relation with developmental competence. Mol Reprod Dev 52, 427-33.

Calder, M. D., Caveney, A. N., Sirard, M. A. and Watson, A. J. (2005). Effect of serum and cumulus cell expansion on marker gene transcripts in bovine cumulus-oocyte complexes during maturation in vitro. Fertil Steril 83 Suppl 1, 1077-85.

Calder, M. D., Caveney, A. N., Smith, L. C. and Watson, A. J. (2003). Responsiveness of bovine cumulus-oocyte-complexes (COC) to porcine and recombinant human FSH, and the effect of COC quality on gonadotropin receptor and Cx43 marker gene mRNAs during maturation in vitro. Reprod Biol Endocrinol 1, 14.

Calder, M. D., Caveney, A. N., Westhusin, M. E. and Watson, A. J. (2001). Cyclooxygenase-2 and prostaglandin E(2)(PGE(2)) receptor messenger RNAs are affected by bovine oocyte maturation time and cumulus-oocyte complex quality, and PGE(2) induces moderate expansion of the bovine cumulus in vitro. Biol Reprod 65, 135-40.

De Sousa, P. A., Westhusin, M. E. and Watson, A. J. (1998). Analysis of variation in relative mRNA abundance for specific gene transcripts in single bovine oocytes and early embryos. Mol Reprod Dev 49, 119-30.

Duchaine, T., Wang, H. J., Luo, M., Steinberg, S. V., Nabi, I. R. and DesGroseillers, L. (2000). A novel murine Staufen isoform modulates the RNA content of Staufen complexes. Mol Cell Biol 20, 5592-601. 
Ecker, D. J., Stein, P., Xu, Z., Williams, C. J., Kopf, G. S., Bilker, W. B., Abel, T. and Schultz, R. M. (2004). Long-term effects of culture of preimplantation mouse embryos on behavior. Proc Natl Acad Sci U S A 101, 1595-600.

Fair, T., Hyttel, P. and Greve, T. (1995). Bovine oocyte diameter in relation to maturational competence and transcriptional activity. Mol Reprod Dev 42, 437-42.

Fan, X. C. and Steitz, J. A. (1998). Overexpression of HuR, a nuclear-cytoplasmic shuttling protein, increases the in vivo stability of ARE-containing mRNAs. Embo $J$ 17, 3448-60.

Gandolfi, T. A. and Gandolfi, F. (2001). The maternal legacy to the embryo: cytoplasmic components and their effects on early development. Theriogenology 55, 1255-76.

Gardner, D. K., Lane, M. and Schoolcraft, W. B. (2002). Physiology and culture of the human blastocyst. J Reprod Immunol 55, 85-100.

Good, P. J. (1995). A conserved family of elav-like genes in vertebrates. Proc Natl Acad Sci U S A 92, 4557-61.

Guhaniyogi, J. and Brewer, G. (2001). Regulation of mRNA stability in mammalian cells. Gene 265, 11-23.

Ho, Y., Doherty, A. S. and Schultz, R. M. (1994). Mouse preimplantation embryo development in vitro: effect of sodium concentration in culture media on RNA synthesis and accumulation and gene expression. Mol Reprod Dev 38, 131-41.

Ho, Y., Wigglesworth, K., Eppig, J. J. and Schultz, R. M. (1995). Preimplantation development of mouse embryos in KSOM: augmentation by amino acids and analysis of gene expression. Mol Reprod Dev 41, 232-8.

Jain, R. G., Andrews, L. G., McGowan, K. M., Pekala, P. H. and Keene, J. D. (1997). Ectopic expression of Hel-N1, an RNA-binding protein, increases glucose transporter (GLUT1) expression in 3T3-L1 adipocytes. Mol Cell Biol 17, 954-62.

Knijn, H. M., Wrenzycki, C., Hendriksen, P. J., Vos, P. L., Herrmann, D., van der Weijden, G. C., Niemann, H. and Dieleman, S. J. (2002). Effects of oocyte maturation regimen on the relative abundance of gene transcripts in bovine blastocysts derived in vitro or in vivo. Reproduction 124, 36575.

Knijn, H. M., Wrenzycki, C., Hendriksen, P. J., Vos, P. L., Zeinstra, E. C., van der Weijden, G. C., Niemann, H. and Dieleman, S. J. (2005). In vitro and in vivo culture effects on mRNA expression of genes involved in metabolism and apoptosis in bovine embryos. Reprod Fertil Dev 17, 775-84.

Lasko, P. (2000). The drosophila melanogaster genome: translation factors and RNA binding proteins. $J$ Cell Biol 150, F51-6.

Leese, H. J. (2002). Quiet please, do not disturb: a hypothesis of embryo metabolism and viability. Bioessays 24, 845-9.

Madan, P., Calder, M. D. and Watson, A. J. (2005). Mitogen-activated protein kinase (MAPK) blockade of bovine preimplantation embryogenesis requires inhibition of both p38 and extracellular signal-regulated kinase (ERK) pathways. Reproduction 130, 41-51.

Mann, M. R., Lee, S. S., Doherty, A. S., Verona, R. I., Nolen, L. D., Schultz, R. M. and Bartolomei, M. S. (2004). Selective loss of imprinting in the placenta following preimplantation development in culture. Development 131, 3727-35.

Marion, R. M., Fortes, P., Beloso, A., Dotti, C. and Ortin, J. (1999). A human sequence homologue of Staufen is an RNA-binding protein that is associated with polysomes and localizes to the rough endoplasmic reticulum. Mol Cell Biol 19, 2212-9.

McEvoy, T. G., Robinson, J. J. and Sinclair, K. D. (2001). Developmental consequences of embryo and cell manipulation in mice and farm animals. Reproduction 122, 507-18. 
McEvoy, T. G., Sinclair, K. D., Young, L. E., Wilmut, I. and Robinson, J. J. (2000). Large offspring syndrome and other consequences of ruminant embryo culture in vitro: relevance to blastocyst culture in human ART. Hum Fertil (Camb) 3, 238-246.

Natale, D. R., Paliga, A. J., Beier, F., D'Souza, S. J. and Watson, A. J. (2004). p38 MAPK signaling during murine preimplantation development. Dev Biol 268, 76-88.

Niemann, H. and Wrenzycki, C. (2000). Alterations of expression of developmentally important genes in preimplantation bovine embryos by in vitro culture conditions: implications for subsequent development. Theriogenology 53, 21-34.

Offenberg, H., Barcroft, L. C., Caveney, A., Viuff, D., Thomsen, P. D. and Watson, A. J. (2000). mRNAs encoding aquaporins are present during murine preimplantation development. Mol Reprod Dev 57, 323-30.

Rinaudo, P. and Schultz, R. M. (2004). Effects of embryo culture on global pattern of gene expression in preimplantation mouse embryos. Reproduction 128, 301-11.

Saunders, L. R. and Barber, G. N. (2003). The dsRNA binding protein family: critical roles, diverse cellular functions. Faseb $\mathrm{J}$ 17, 961-83.

Schultz, R. M. (2005). From egg to embryo: a peripatetic journey. Reproduction 130, 825-8.

Schultz, R. M. and Williams, C. J. (2002). The science of ART. Science 296, 2188-90.

Sinclair, K. D., McEvoy, T. G., Maxfield, E. K., Maltin, C. A., Young, L. E., Wilmut, I., Broadbent, P. J. and Robinson, J. J. (1999). Aberrant fetal growth and development after in vitro culture of sheep zygotes. J Reprod Fertil 116, 177-86.

Sinclair, K. D., Rooke, J. A. and McEvoy, T. G. (2003). Regulation of nutrient uptake and metabolism in pre-elongation ruminant embryos. Reprod Suppl 61, 371-85.

St Johnston, D., Beuchle, D. and Nusslein-Volhard, C. (1991). Staufen, a gene required to localize maternal RNAs in the Drosophila egg. Cell 66, 51-63.

Telford, N. A., Watson, A. J. and Schultz, G. A. (1990). Transition from maternal to embryonic control in early mammalian development: a comparison of several species. Mol Reprod Dev 26, 90-100.

Temeles, G. L. and Schultz, R. M. (1997). Transient polyadenylation of a maternal mRNA following fertilization of mouse eggs. J Reprod Fertil 109, 223-8.

van Wagtendonk-de Leeuw, A. M., Mullaart, E., de Roos, A. P., Merton, J. S., den Daas, J. H., Kemp, B. and de Ruigh, L. (2000). Effects of different reproduction techniques: AI MOET or IVP, on health and welfare of bovine offspring. Theriogenology 53, 575-97.

Watson, A. J., De Sousa, P., Caveney, A., Barcroft, L. C., Natale, D., Urquhart, J. and Westhusin, M. E. (2000). Impact of bovine oocyte maturation media on oocyte transcript levels, blastocyst development, cell number, and apoptosis. Biol Reprod 62, 355-64.

Wrenzycki, C., Herrmann, D., Carnwath, J. W. and Niemann, H. (1999). Alterations in the relative abundance of gene transcripts in preimplantation bovine embryos cultured in medium supplemented with either serum or PVA. Mol Reprod Dev 53, 8-18.

Wrenzycki, C., Herrmann, D., Lucas-Hahn, A., Korsawe, K., Lemme, E. and Niemann, H. (2005). Messenger RNA expression patterns in bovine embryos derived from in vitro procedures and their implications for development. Reprod Fertil Dev 17, 23-35.

Yang, J., Medvedev, S., Reddi, P. P., Schultz, R. M. and Hecht, N. B. (2005). The DNA/RNAbinding protein MSY2 marks specific transcripts for cytoplasmic storage in mouse male germ cells. Proc Natl Acad Sci U S A 102, 1513-8.

Yang, J., Medvedev, S., Yu, J., Schultz, R. M. and Hecht, N. B. (2006). Deletion of the DNA/RNAbinding protein MSY2 leads to post-meiotic arrest. Mol Cell Endocrinol 250, 20-4. 
Yang, J., Medvedev, S., Yu, J., Tang, L. C., Agno, J. E., Matzuk, M. M., Schultz, R. M. and Hecht, N. B. (2005). Absence of the DNA-/RNA-binding protein MSY2 results in male and female infertility. Proc Natl Acad Sci U S A 102, 5755-60.

Yu, J., Hecht, N. B. and Schultz, R. M. (2003). Requirement for RNA-binding activity of MSY2 for cytoplasmic localization and retention in mouse oocytes. Dev Biol 255, 249-62. 
Table 1. Primers used to detect RBP mRNAs in cow oocytes and embryos

\begin{tabular}{|l|l|l|l|l|l|}
\hline & & Sequence & $\begin{array}{l}\text { Anneal } \\
\text { Temp. }\end{array}$ & $\begin{array}{l}\text { Size } \\
\text { in bp }\end{array}$ & Accession \# \\
\hline STAU1 & 5 & ATTTCCAGTC/TCCACCTTTAC & 53 & $\begin{array}{l}318 \mathrm{bp} \\
300 \mathrm{bp}\end{array}$ & $\begin{array}{l}\text { BC082277 mouse } \\
\text { NM_001037328 human }\end{array}$ \\
\hline STAU1 & $3^{\prime}$ & TGGTCACAAAGTTCTTCAT & & & $\begin{array}{l}\text { BC082277 mouse } \\
\text { NM_001037328 human }\end{array}$ \\
\hline STAU2 & $5^{\prime}$ & GAAGTTGCTACTGGAACAGG & 52 & $342 \mathrm{bp}$ & XM_872380 cow \\
\hline STAU2 & $3^{\prime}$ & AGCTGAACTACTCGATGTGG & & & XM_872380 cow \\
\hline ELAVL1 & 5 & AAGACCACATGGCG/CGAAGAC & 59 & $474 \mathrm{bp}$ & $\begin{array}{l}\text { NM_010485 mouse } \\
\text { NM_001419 human }\end{array}$ \\
\hline ELAVL1 & $3^{\prime}$ & TTGCCTCTTCTGCC/TTCC/TGAC & & & $\begin{array}{l}\text { NM_010485 mouse } \\
\text { NM_001419 human }\end{array}$ \\
\hline ELAVL2 & 5 & AGGTCACTGGCATATCAAGG & 55 & $\begin{array}{l}539 \mathrm{bp} \\
500-506 \mathrm{bp}\end{array}$ & $\begin{array}{l}\text { NM_207686 mouse } \\
\text { NM_004432 human }\end{array}$ \\
\hline ELAVL2 & 3, & TCCATTGAGGCTAC/GC/GTATCG & & & $\begin{array}{l}\text { NM_207686 mouse } \\
\text { NM_004432 human }\end{array}$ \\
\hline
\end{tabular}


Fig 1. Staufen mRNA and protein during cow preimplantation development. A: Staufen 1; B: Staufen 2; C-K: Staufen protein in cow oocytes and embryos. Green is FITC-labeled 2' antibody against rabbit anti-staufen. Red is rhodamine-phalloidin stain for F-actin. Blue is DAPI stained nuclei. GV-germinal vesicle stage; 24h, in vitro matured 24h; Mat-matured 24h in vitro; 1c-1 cell stage; 2c-2 cell stage; 4c-4 cell stage; 8c-8 cell stage; Mor-morula stage; Bl-blastocyst stage; Neg-negative control; MW, 100bp molecular weight standard; +, positive control tissue, br=brain. Bar is approximately $50 \mu \mathrm{m}$. $\mathrm{N}=3$ replicates, 25-39 embryos examined at each stage.

Fig.2. ELAVL mRNA and protein during cow preimplantation development. A: ELAVL1; B: ELAVL2; C-K ELAVL1 protein, N=3 replicates, 29-48 embryos examined at each stage; L-T ELAVL2 protein, $\mathrm{N}=3$ replicates, 25-43 embryos examined at each stage. Green is FITC-labeled 2' antibody against rabbit anti-ELAVL1 or 2. Red is rhodamine-phalloidin stain for F-actin. Blue is DAPI stained nuclei. GVgerminal vesicle stage; 24h, in vitro matured 24h; Mat-matured 24h in vitro; 1c-1 cell stage; 2c-2 cell stage; 4c-4 cell stage; 8c-8 cell stage; Mor-morula stage; Bl-blastocyst stage; Neg-negative control; MW, 100bp molecular weight standard; +, positive control tissue, br=brain, gc=granulosa cells. Bar is approximately $50 \mu \mathrm{m}$. 
Fig.1. Staufen mRNA and Protein During Cow Preimplantation Development

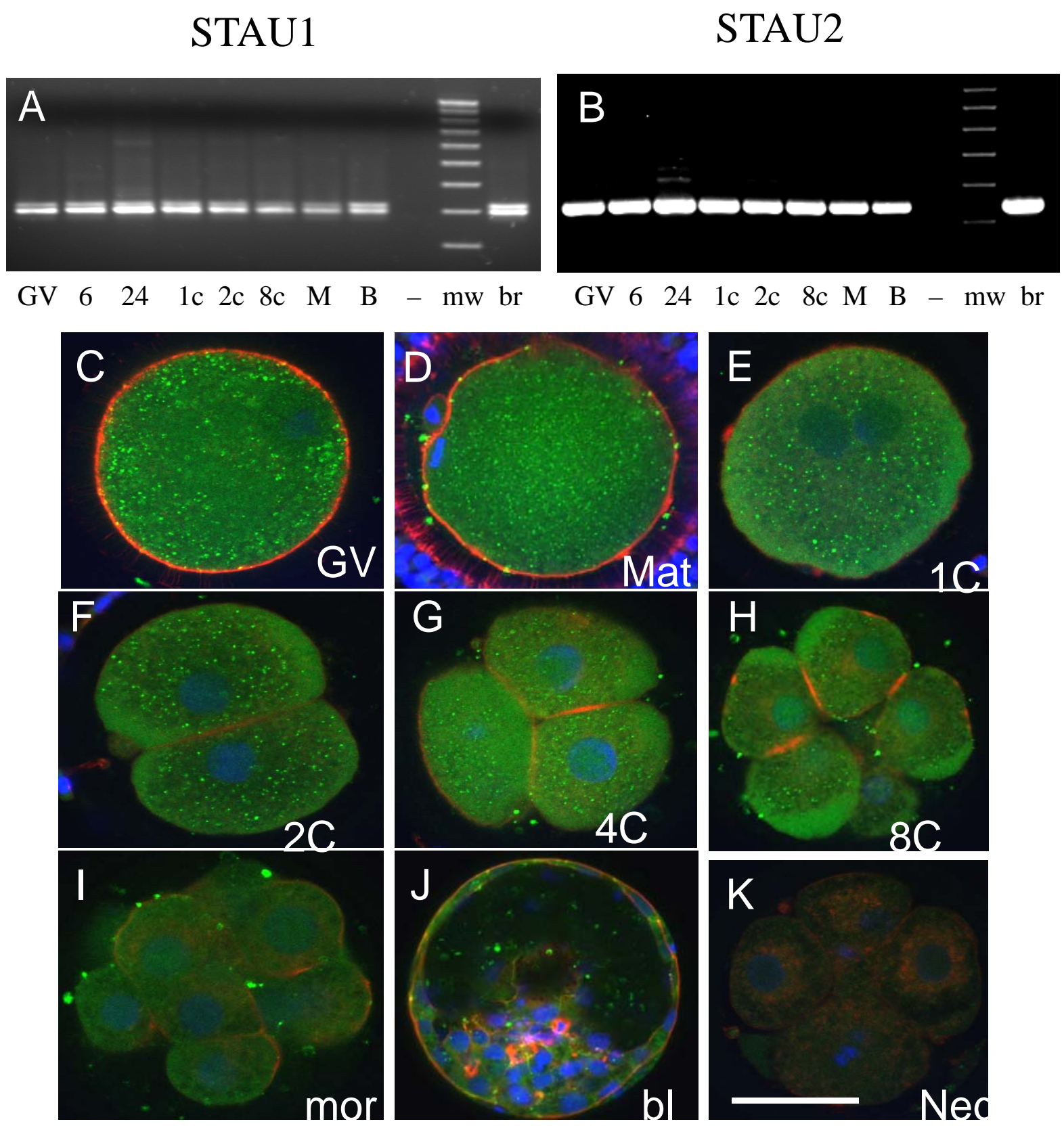


Fig. 2. ELAV mRNA and Protein During Cow Preimplantation Development

ELAVL1

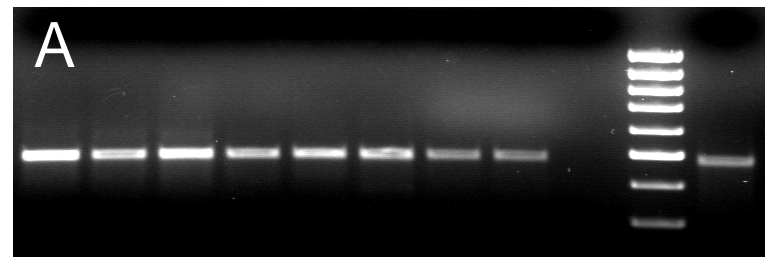

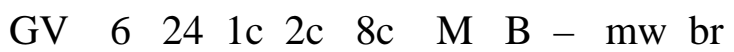

ELAVL2

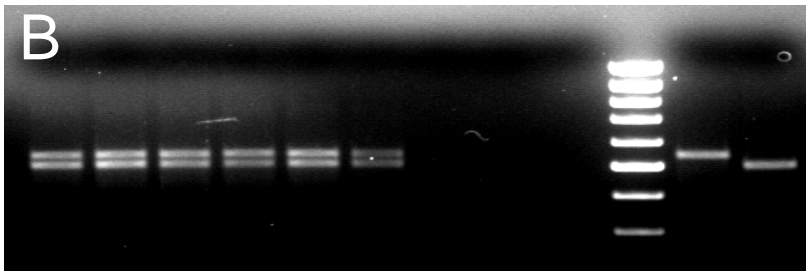

GV 624 1c 2c 8 c $\quad$ M B - mw br gc
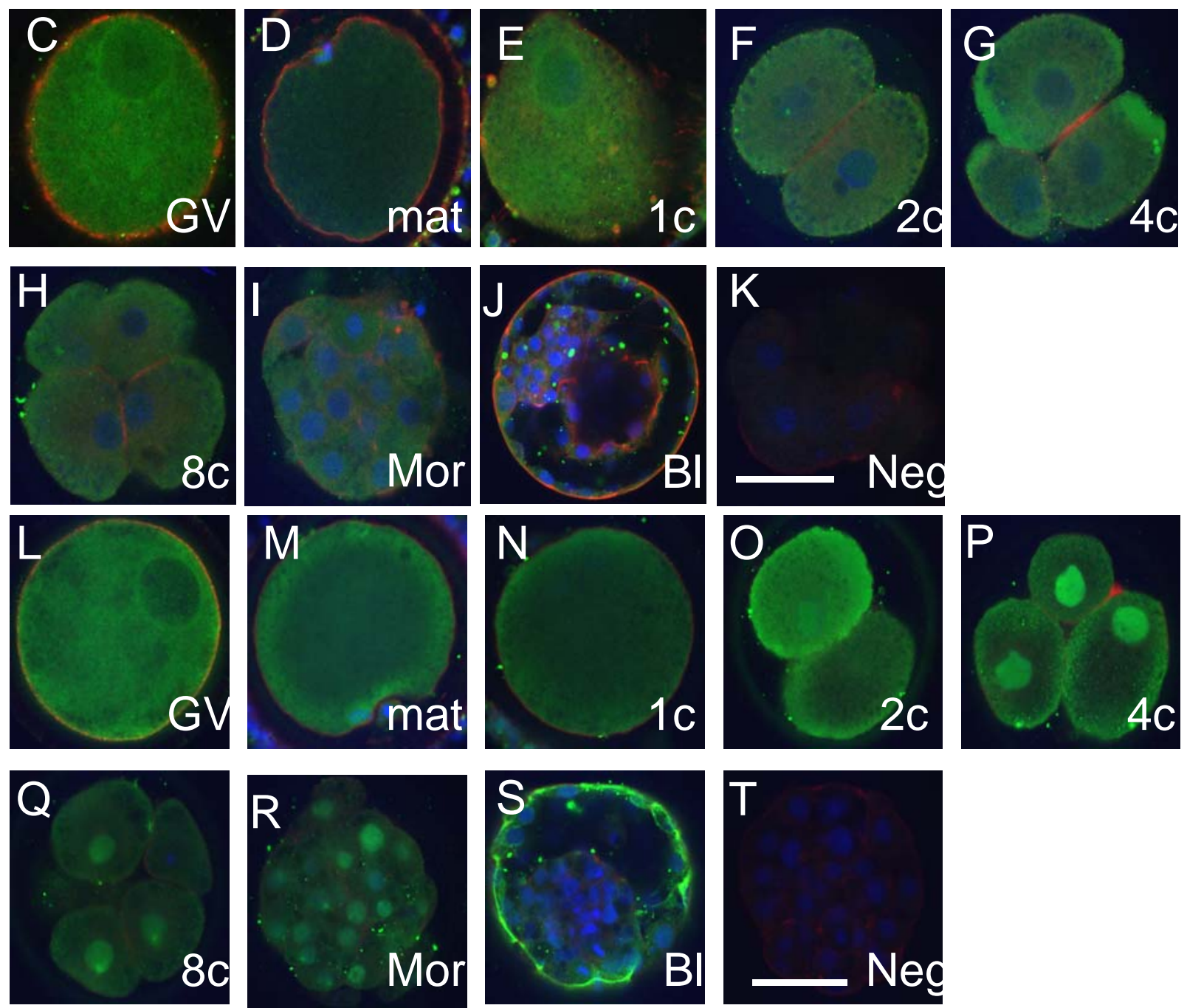